\title{
Removal of Congo Red Dye using Synthesised Copper(II) Activated Carbon from Date Seeds
}

\author{
Hazirah Syahirah Zakria ${ }^{1}$, Siti Nor Atika Baharin ${ }^{1}$, Nurul’ Ain Jamion ${ }^{1,2}$ and Nur Rahimah Said ${ }^{1 *}$ \\ ${ }^{\text {IS }}$ chool of Chemistry and Environment, Faculty of Applied Sciences, Universiti Teknologi MARA (UiTM), Cawangan \\ Negeri Sembilan, Kampus Kuala Pilah, 72000 Kuala Pilah, Negeri Sembilan, Malaysia \\ ${ }^{2}$ Research Centre for Sustainability Science \& Governance (SGK), Institute for Environment and Development
}

(LESTARI), Universiti Kebangsaan Malaysia, 43600 Bangi, Selangor, Malaysia

\begin{abstract}
Azo dyes are recognised as contaminants from the textile and printing industries that lead to human toxicity. Copper(II) activated carbon ( $\mathrm{CuAC}$ ) is an effective removal agent of dyes in these industries. The purpose of this study is to synthesise and characterise CuAC from date seeds. In addition, the efficiency of $\mathrm{CuAC}$ as a removal of Congo red (CR) in aqueous solution is also studied. Activated carbon (AC) was prepared from date seeds using phosphoric acid as activating agent, followed by activation process in a furnace at $500{ }^{\circ} \mathrm{C}$ for 2 hours. Copper(II) nitrate was used in the impregnation of $\mathrm{AC}$ to produce $\mathrm{CuAC}$. The $\mathrm{AC}$ and $\mathrm{CuAC}$ were characterised using Attenuated Total Reflectance Fourier-Transform Infrared Spectroscopy (ATR-FTIR), BET surface area (SBET), Scanning Electron Microscope-Energy Dispersive X-Ray Spectroscopy (SEM-EDX), Atomic Absorption Spectroscopy (AAS) and X-Ray Diffraction (XRD). UV-VIS Spectroscopy was used to determine dye concentrations after treatment with removal agent of $\mathrm{CuAC}$. The characterisation data proved that the $\mathrm{CuAC}$ has been successfully synthesised with $0.33 \% \mathrm{Cu}$ (II) loaded onto AC and its surface area increased from $8.37 \mathrm{~m}^{2} / \mathrm{g}$ to $384.82 \mathrm{~m}^{2} / \mathrm{g}$. The dye removal study was conducted at $10 \mathrm{ppm}$ concentration of dye. Result revealed that $0.2 \mathrm{~g}$ of $\mathrm{CuAC}$ at $\mathrm{pH} 2$ in 90 min removed $100 \%$ of CR dye.
\end{abstract}

Keywords: Copper(II) activated carbon; date seeds activated carbon; congo red; dye removal

\section{INTRODUCTION}

Azo dyes are prepared by diazotisation of an aromatic amine and coupling with either phenol or naphthol. The aromatic amine (often $\mathrm{N}$-alkylated) contains an acidic proton or active methylene group. This type of dye absorbed by the human body can undergo reduction decomposition to form carcinogenic amines due to enzymes in the body that have reduction properties. It causes health problems such as respiratory problems, skin sensitisation and carcinogenicity (Chavan, 2011). In addition, colours in dyes cause limit the underwater vision, restrain the aquatic plants from undergo a photosynthesis as well as toxic to aquatic life when large amount of dyes been release into the water stream (Chen et al., 2019).
According to Berkane et al. (2019), dyes can be divided into three categories: anionic, cationic and non-ionic. Congo red is one type of azo dyes which is a benzidine-based anionic dye composed with two azo groups that been widely reported used in the industries. Congo red dye with the molecular formula of $\mathrm{C}_{32} \mathrm{H}_{22} \mathrm{~N}_{6} \mathrm{Na}_{2} \mathrm{O}_{6} \mathrm{~S}_{2}$ can cause various health and environmental problems such as cancer and gene alteration if large amount of congo red was consumed (Shah et al., 2020).

Industries such as textile, cosmetic, food and paper usually use the dyes and release the wastewater into water bodies (Kaur et al., 2012). Before that, wastewater treatment for dye removal is strongly needed to prevent the negative effect of dye to the environment. The dyes such as congo red has a complex structure that is consequently difficult to remove

*Corresponding author's e-mail: nurra1435@uitm.edu.my 
and degrade in natural condition (Chen et al., 2019). There are a few popular methods to remove dyes from wastewater such as ultra-filtration, biosorption, oxidation, biodegradation, adsorption, and ion-exchange (Wang et al., 2011; Jamion et al., 2017).

The adsorption process is one of the significant methods of advanced wastewater treatment to minimise the dangerous organic and inorganic compounds left in effluents (Khodaie et al., 2013). This adsorption treatment gains a wide attention due to greater efficiency, non-toxic components, inexpensive, and simple removal (Shu et al., 2017). The adsorption phenomenon depends on the interaction between the adsorbent's surface and the adsorbed species. The interaction may be due to chemical bonding, hydrogen bonding, hydrophobic and van der Waals forces. Activated carbon as adsorbent is an example of adsorption occurrence which is widely used in water treatment.

The activated carbon (AC) is a type of carbonaceous material that is rich in carbon and has large surface areas, non-toxic property, high porosity, and the ability to contain different functional groups (Hussein et al., 2015). These features make activated carbon a very versatile and resourceful material (Aldawsari et al., 2017). The development of economical adsorbents using waste materials has gained a lot of attraction. Several research studies reported a great deal on removal of heavy metals and dyes from water using waste material as an adsorbent. It can be prepared from agricultural waste such as wood, coal, peat, date seeds, coconut shells, nutshells, bones and fruit stone by chemical and physical activation (Salman et al., 2015). Date seeds possess natural structure which contain lignocellulosic composition as well as low in ash content that nominating it to become one of the best starting materials in production of activated carbon (Krishnamoorthy et al., 2019).

The chemical activation is a better method with single-stage process using phosphoric acid, nitric acid, zinc chloride, and bases such as sodium hydroxide and potassium hydroxide. An advantage of chemical activation is it will decelerate the formation of tar during thermal degradation of lignocellulosic material in the presence of a dehydrating agent. Moreover, it has been well recorded that the activation temperatures are low, while the porous carbon yield is high in chemical activation process compared to physical activation. It will also break down the cellulosic material and suitable pore structure will be created from the carbonisation process as a result of dehydration (Oboh et al., 2018). Phosphoric acid is more preferred as a chemical activation agent compared to zinc chloride and others since it is eco-friendly and widely used in pharmaceutical and food industries (Al-Balushi et al., 2017; Reddy et al., 2015).

Deposit of metal element such as copper(II) into activated carbon has improved the adsorption capacity of dye in aqueous solution (Shu et al., 2017). This type of dye removal is responsive as adsorbent and catalyst to remove dye due to its photocatalytic activity. However, commercially activated carbon is relatively expensive, so it is an interesting challenge to synthesise and make a relatively cheap activated carbon from agricultural waste (Hussein et al., 2015).

This study focused on the synthesis of copper(II) activated carbon for dye removal. The AC was synthesised from date seed waste and believed to be a good, low-toxic and economical dye removal agent.

\section{MATERIALS AND METHOD}

\section{A. Materials}

Fresh Ajwa Dates Grade AA (1 kg) from Bani Hasyim Farm, Medina, Saudi Arabia were purchased and used as raw material. The seeds were collected by removing the date pericarps. The chemicals used were $30 \%$ and $85 \%$ aqueous solution of phosphoric acid $\left(\mathrm{H}_{3} \mathrm{PO}_{4}\right)$, copper nitrate $\left(\mathrm{Cu}\left(\mathrm{NO}_{3}\right)_{2}\right)$, congo red (CR), 2.o M sodium hydroxide $(\mathrm{NaOH})$ solution, 12.0 M hydrochloric acid solution ( $\mathrm{HCl})$, silica gel, deionised water and distilled water.

\section{B. Dye Removal Agent Preparation}

\section{Preparation of activated carbon (AC)}

Date seeds (100 g) were washed with water and dried in an oven at $90^{\circ} \mathrm{C}$ for $2 \mathrm{~h}$. Dry samples were crushed with hammer and ground using a food grinder to get powdered date seeds. The pre-treated process continued when the powdered date seed was immersed in $250 \mathrm{~mL}$ of $30 \%$ aqueous solution of phosphoric acid for $24 \mathrm{~h}$ to give acidic conditions and washed using distilled water, filtered using vacuum filtration technique and dried under room temperature. The dried 
powder date seed was pre-treated by impregnating it with $85 \%$ of concentrated phosphoric acid with the ratio of 2:1 (200 mL of phosphoric acid: $100 \mathrm{~g}$ of date seed). The mixture was heated using a hot plate by double boiling at a temperature range between $70^{\circ} \mathrm{C}$ to $90^{\circ} \mathrm{C}$ for $4 \mathrm{~h}$. The drying procedure was carried out for about $24 \mathrm{~h}$ in the oven at $110^{\circ} \mathrm{C}$. The activation process continued in the muffle furnace at $500^{\circ} \mathrm{C}$ for $2 \mathrm{~h}$. The product was activated carbon (AC) and washed with distilled water using the vacuum filtration technique. The prepared $\mathrm{AC}$ was dried in the oven at $90^{\circ} \mathrm{C}$ for $3 \mathrm{~h}$. Lastly, the sample was kept in a desiccator and ready for the preparation of copper(II) activated carbon (CuAC) (Hilal et al., 2012; Jamion et al., 2017; Ogungbenro et al., 2018).

\section{Preparation of Copper(II) Activated Carbon (CuAC)}

Mass of $30 \mathrm{~g}$ of the prepared $\mathrm{AC}$ was immersed in $150 \mathrm{~mL}$ of o.o5 $\mathrm{M}$ copper(II) nitrate $\left(\mathrm{Cu}\left(\mathrm{NO}_{3}\right)_{2}\right)$ solution. The mixture was shaken with $100 \mathrm{rpm}$ of rotation rate for $24 \mathrm{~h}$. The $\mathrm{CuAC}$ was filtered and dried at $105{ }^{\circ} \mathrm{C}$ for $24 \mathrm{~h}$ (Huang et al., 2006).

\section{Characterisation}

The functional groups of $\mathrm{AC}$ and $\mathrm{CuAC}$ were observed using Perkin Elmer Spectrum 100 FT-IR spectrometer with a reaction range of experiment between $4000 \mathrm{~cm}^{-1}$ to $650 \mathrm{~cm}^{-1}$ as attenuated by the total reactance (ATR).

The pore structural analysis of prepared $\mathrm{AC}$ and $\mathrm{CuAC}$ was done using nitrogen adsorption at $77 \mathrm{~K}$ surface area analyser, Micromeritics ASAP 2010. The surface of the sample was physically adsorbed by nitrogen gas and out-gassed under vacuum at $100{ }^{\circ} \mathrm{C}$ for 12 hours (Shu et al., 2017).

The morphology of AC and CuAC was analysed using SEM Tescan VEGA3. The samples were coated with gold in a thickness range of 30-40 $\mathrm{nm}$ and equipped with EDX Oxford instruments x-act Model Series 118-0101. The EDX is an elemental analysis technique that gives the information of the element present in the sample.

Percentage of $\mathrm{Cu}^{2+}$ deposited onto the $\mathrm{CuAC}$ was analysed by AAS. Mass of $0.1 \mathrm{~g}$ of $\mathrm{CuAC}$ was digested with $5 \mathrm{~mL}$ concentrated $\mathrm{HCl}$ and heated for $30 \mathrm{~min}$. Then, the solution was transferred into a $25 \mathrm{~mL}$ volumetric flask and deionised water was added to the mark. The sample was heated for boiling and filtered through filter paper. The filtrate was determined by the Perkin Elmer Atomic Absorption
Spectrometer Analyst 700 at $324.8 \mathrm{~nm}$ (Huang et al., 2006).

The crystalline structure of $\mathrm{Cu}$ and $\mathrm{CuAC}$ were observed using Powder XRD at room temperature. The samples were scanned from $5^{\circ}$ to $70^{\circ} 2 \theta$ angles using a step interval $0.02^{\circ}$ and scan speed of $5 \mathrm{~min}^{-1}$.

\section{Dyes Removal Study}

The CR solution with concentration of $10.0 \mathrm{ppm}$ were prepared. The 1.o M sodium hydroxide $(\mathrm{NaOH})$ and 12.0 $\mathrm{M}$ hydrochloric acid ( $\mathrm{HCl})$ were added to the dye solution to control the pH condition (Nasron et al., 2018). The prepared $\mathrm{CuAC}$ was added into $10.0 \mathrm{ppm}$ of $100 \mathrm{~mL}$ of dye solution in beaker at $\mathrm{pH}$ 2. The mixture was stirred with speed of 300 rpm for $90 \mathrm{~min}$. Then, the dye solution was taken at each 15 min interval and keep for further analysis (Oboh et al., 2018). The process was repeated at different $\mathrm{pH}$ which are $\mathrm{pH} 7$ and 10, respectively. The effect of light and the effect of $\mathrm{CuAC}$ mass (0.2 $\mathrm{g}$ and $0.3 \mathrm{~g}$ ) also conducted. The residual concentration of dyes in the solution were determined from UV-vis and the \% removal of dye was calculated by using the Equation (1) (Oboh et al., 2018).

$$
\% \text { Removal }=\frac{C_{1}-C_{2}}{C_{1}} \times 100
$$

Where, $\mathrm{C}_{1}$ was initial concentration while $\mathrm{C}_{2}$ was final concentration of dyes solution.

\section{RESULTS AND DISCUSSION}

\section{A. Synthesis of $A C$ and $C u A C$}

Powdered date seed turned from brown colour to black paste when heated with $85 \%$ concentrated $\mathrm{H}_{3} \mathrm{PO}_{4}$ at temperature range between $70-90^{\circ} \mathrm{C}$ for $4 \mathrm{~h}$. The black paste turned to dry carbon when the mixture was heated in the oven for $24 \mathrm{~h}$ at $110^{\circ} \mathrm{C}$ and continued being heated in a muffle furnace for $2 \mathrm{~h}$ at $500^{\circ} \mathrm{C}$, resulting in hard brittle black carbon called as AC. After impregnation of $\mathrm{AC}$ with copper to form $\mathrm{CuAC}$, the colour changed from black to grey and gained $91.30 \%$ of yield.

\section{B. Characterisation of $A C$ and $C u A C$}

The FTIR spectra of AC and CuAC are displayed in Figure 1. Both spectra show similar vibration band characteristics (Shu et al., 2017). Absorption band of $\mathrm{C}-\mathrm{H}$ can be observed at 2763 
$\mathrm{cm}^{-1}$ in $\mathrm{AC}$ and $2792 \mathrm{~cm}^{-1}$ in CuAC spectra. The existence of carbonyl group $(\mathrm{C}=\mathrm{O})$ can be seen at absorption band of 1615 $\mathrm{cm}^{-1}$ in AC spectra and $1593 \mathrm{~cm}^{-1}$ in CuAC spectra. Meanwhile, the presence of $\mathrm{P}-\mathrm{O}-\mathrm{C}$ appeared at 1286 and $993 \mathrm{~cm}^{-1}$ in $\mathrm{AC}$ and 1277 and $1066 \mathrm{~cm}^{-1}$ in CuAC spectra. The presence of P$\mathrm{O}$ group in the structure of $\mathrm{AC}$ and $\mathrm{CuAC}$ was due to the phosphorus acid used in the preparation process of activated carbon (Jamion et al., 2017). The intensity of P-O absorption band of $\mathrm{CuAC}$ was lower compared to $\mathrm{AC}$ which could be due to the reduction in the number of $\mathrm{P}-\mathrm{O}$ attached to the surface of $\mathrm{AC}$ after $\mathrm{Cu}(\mathrm{II})$ loading in the formation of $\mathrm{CuAC}$.

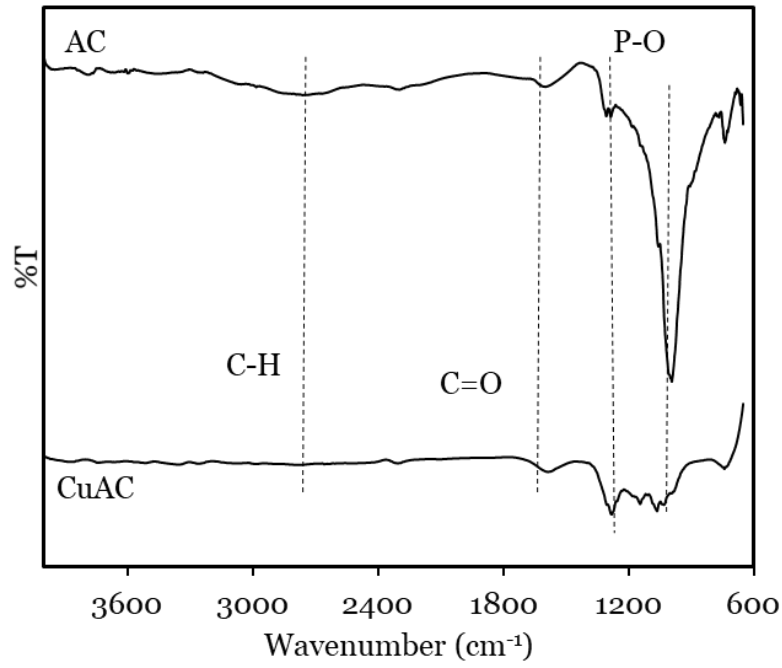

Figure 1. FTIR spectra of $\mathrm{AC}$ and $\mathrm{CuAC}$

The data are listed in Table 1 . From the table, the BET surface area (SBET) of CuAC was higher which was 384.8175 $\mathrm{m}^{2} / \mathrm{g}$ compared to $\mathrm{AC}$ which was $8.3742 \mathrm{~m}^{2} / \mathrm{g}$. This indicated that the $\mathrm{Cu}$ (II) loaded on the surface of activated carbon helped in the evolution of higher surface area. The total pore volume of $\mathrm{AC}$ was $0.03632 \mathrm{~cm}^{3} / \mathrm{g}$ with the average pore diameter of $20.4707 \mathrm{~nm}$. Meanwhile, CuAC had 0.38847 $\mathrm{cm}^{3} / \mathrm{g}$ of total pore volume with the average pore diameter of $5.8393 \mathrm{~nm}$.

Table 1. The specific surface area, total pores volume and average pores diameter of $\mathrm{AC}$ and $\mathrm{CuAC}$

\begin{tabular}{cccc}
\hline Sample & $\begin{array}{c}\text { Specific } \\
\text { surface } \\
\text { area, } \mathbf{S}_{\text {BET }} \\
\left(\mathbf{m}^{\mathbf{2}} / \mathbf{g}\right)\end{array}$ & $\begin{array}{c}\text { Total pores } \\
\text { volume, } \mathbf{V} \\
(\mathbf{c m} \mathbf{3} / \mathbf{g})\end{array}$ & $\begin{array}{c}\text { Average } \\
\text { pores } \\
\text { diameter, } \mathbf{d} \\
\mathbf{( n m )}\end{array}$ \\
\hline $\mathrm{AC}$ & 8.3741 & 0.03632 & 20.4707 \\
$\mathrm{CuAC}$ & 384.8175 & 0.38847 & 5.8393 \\
\hline
\end{tabular}

Figure 2 shows the pore size distribution graph. The AC has the mesopore type represented by larger peaks between pore diameters of $4 \mathrm{~nm}$ to $50 \mathrm{~nm}$ (Dias et al, 2007). This occurrence was due to the effectiveness of phosphoric acid producing larger pores. Meanwhile, for $\mathrm{CuAC}$, the majority of pore volume was at 5-10 $\mathrm{nm}$ due to the $\mathrm{Cu}^{2+}$ loaded on the surface. Thus, AC and CuAC exhibited well-developed porous structures which contained mesopores.

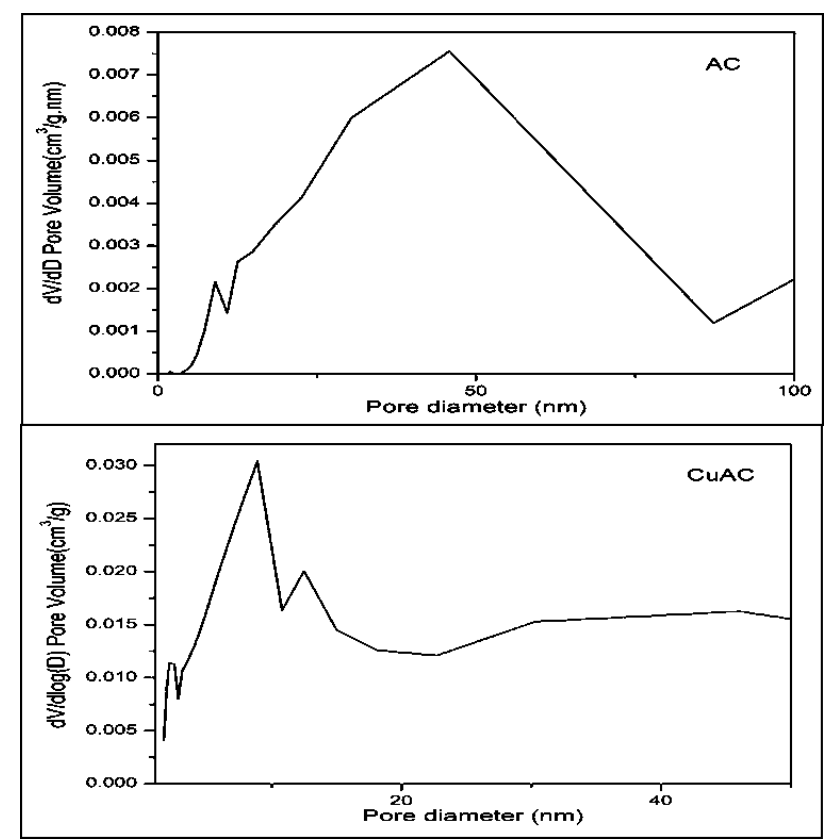

Figure 2. Pore size distribution of $\mathrm{AC}$ and $\mathrm{CuAC}$

The $\mathrm{N}_{2}$ adsorption-desorption isotherms of $\mathrm{AC}$ and $\mathrm{CuAC}$ are shown in Figure 3 and can be assigned as Type IV according to IUPAC classification. This occurred due to the hysteresis loop which was associated with capillary condensation taking place in the mesopores. The graph approached the limiting value at $\mathrm{P} / \mathrm{P}_{\mathrm{o}}$. The graph of $\mathrm{AC}$ was confirmed by hysteresis loops type H3. The shape was aggregated and had plate-like particles forming slit-like pores. Meanwhile, the hysteresis loops of $\mathrm{CuAC}$ were classified as $\mathrm{H}_{4}$ type. The shape was narrow slit-like pores, with irregular particles, broad size distribution and hollow spheres composed of mesopores (Foo \& Hameed, 2010). 

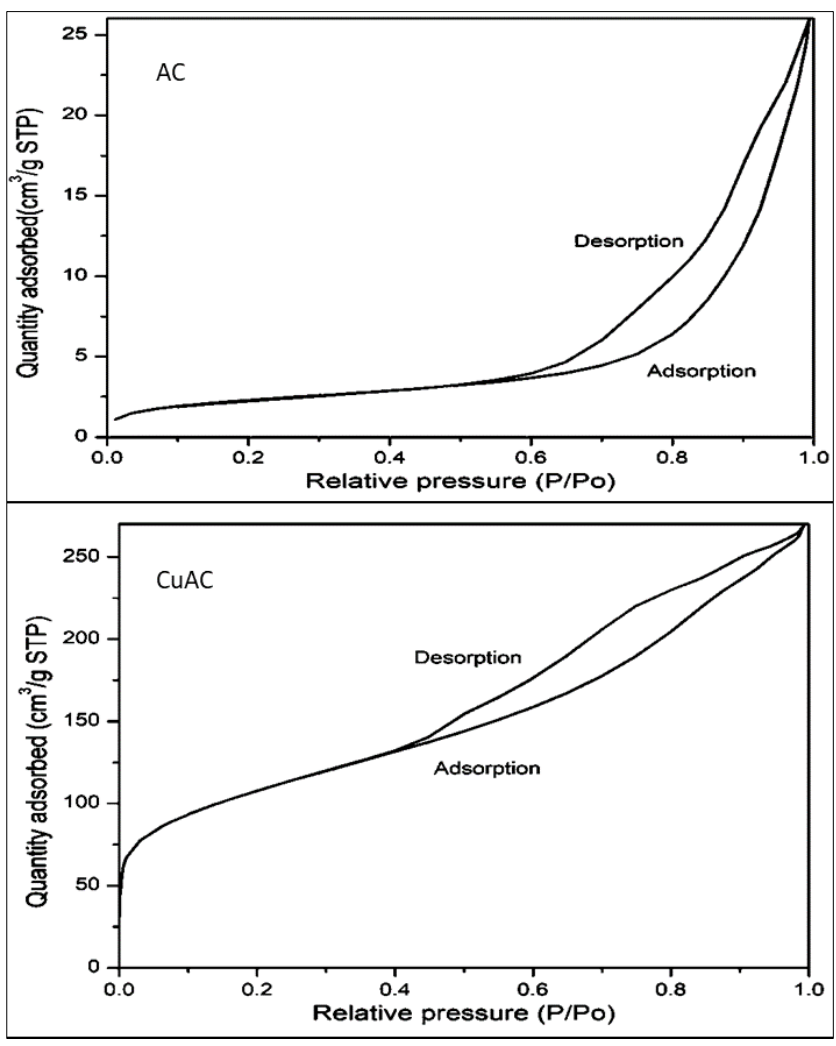

Figure 3. $\mathrm{N}_{2}$ Adsorption-Desorption Isotherm of $\mathrm{AC}$ and $\mathrm{CuAC}$

The SEM micrographs of AC and CuAC with magnification 1.97 Kx and 1.50 Kx are shown in Figure 4. Both micrographs show the pores have been well developed on the external surface with oval and circular patterns. This phenomenon occurred due to the activation process using phosphoric acid as activating agent to create pores on activated carbon and increase pore volume (Jamion et al., 2017). The AC had a larger pore structure suitable for $\mathrm{Cu}(\mathrm{II})$ ions to be loaded on it, in the formation of $\mathrm{CuAC}$ (Shu et al., 2017). After $\mathrm{Cu}$ (II) was loaded, the morphology was changed with the abundant pore formation with higher surface area suitable for the dyes trapped, leading to higher adsorption capacity.
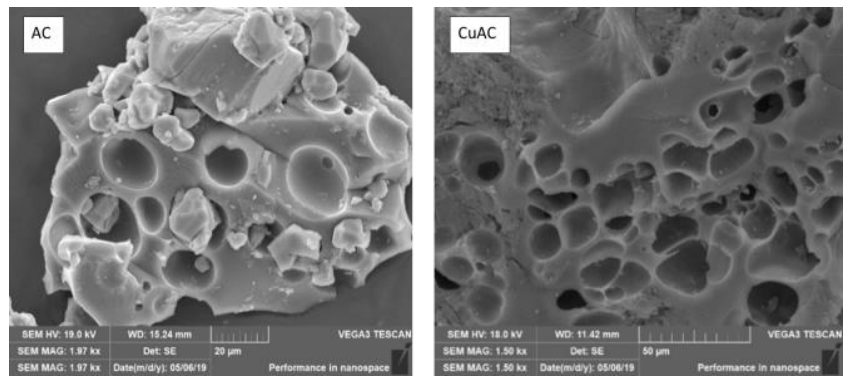

Figure 4. SEM micrograph of $\mathrm{AC}$ and $\mathrm{CuAC}$
The Energy Dispersive X-ray (EDX) spectrum in Figure 5 shows the surface composition of $\mathrm{AC}$ and $\mathrm{CuAC}$. $\mathrm{Cu}$ (II) was seen present in the EDX spectrum which indicated that $\mathrm{Cu}$ (II) was successfully loaded on the activated carbon surface. Meanwhile, the element percentages of $\mathrm{AC}$ and $\mathrm{CuAC}$ are tabulated in the inserted table. For AC, the presence of $37.34 \%$ of oxygen (O), 32.75\% carbon (C) and $29.90 \%$ phosphorus (P) on AC surface can be seen. The higher percentage of oxygen and carbon determined that the date seed had higher content of fixed carbon. Phosphorus element was present due to the phosphorus acid used as activating agent. Phosphorus compound strongly bounded with oxygen and carbon (Jamion et al., 2017). For CuAC, the presence of $79.43 \%$ carbon $(\mathrm{C})$ and $20.57 \%$ copper $(\mathrm{Cu})$ on AC surface was detected.

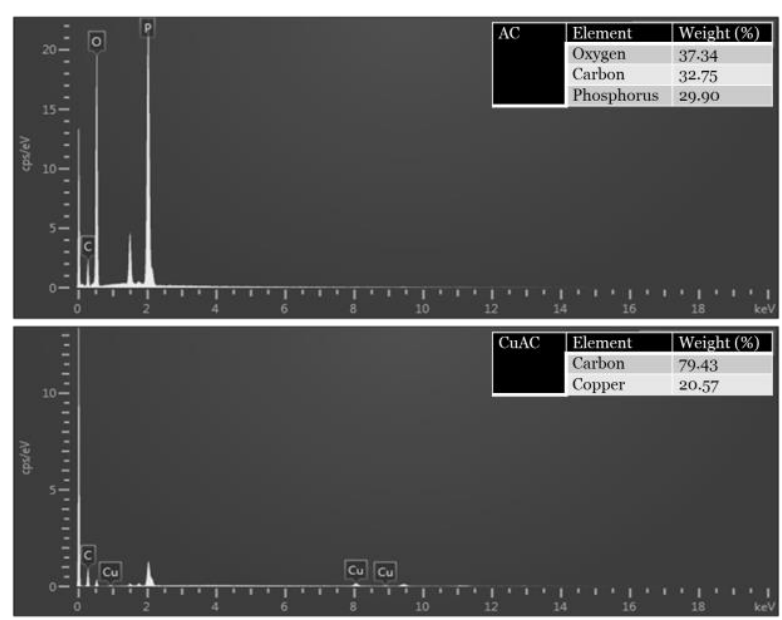

Figure 5. EDX spectrum of $\mathrm{AC}$ and $\mathrm{CuAC}$

Mass of $30 \mathrm{~g}$ of $\mathrm{AC}$ was immersed in the $0.05 \mathrm{M}\left(\mathrm{Cu}\left(\mathrm{NO}_{3}\right)_{2}\right)$ to become CuAC. AAS was used to analyse the amount of $\mathrm{Cu}$ (II) that was successfully loaded on the CuAC surface. In this study, $0.1 \mathrm{~g}$ of $\mathrm{CuAC}$ was used. The AAS result shows that in $0.1 \mathrm{~g}$ of $\mathrm{CuAC}, 0.327 \% \mathrm{Cu}$ (II) was successfully loaded on AC. The good loading of $\mathrm{Cu}(\mathrm{II})$ on the surface of $\mathrm{CuAC}$ was due to the small diameter molecule of $\mathrm{Cu}$ (II) that can easily enter into the pore of $\mathrm{AC}$ and consequently increased the surface area after $\mathrm{CuAC}$ was formed. $\mathrm{Cu}$ (II) molecule penetrated deep into the $\mathrm{AC}$ pores to increase the pore volume (Shu et al., 2017).

Figure 6 demonstrates the XRD spectra of AC and CuAC. The XRD analysis of CuAC shows one small diffraction peak corresponding to $\mathrm{Cu}(\mathrm{II})$ at 45.480 (Shu et al., 2017; Manuel et al., 2018), thus proving that the surface of activated carbon 
was loaded with $\mathrm{Cu}(\mathrm{II})$. Furthermore, the diffraction peak shows sharp nature which contribute to the crystalline nature of synthesized CuAC (Iqbal et al., 2019). Diffraction peak shown was very small due to only $0.327 \% \mathrm{Cu}$ (II) loaded on $0.1 \mathrm{~g} \mathrm{CuAC}$ surface as found in AAS analysis.

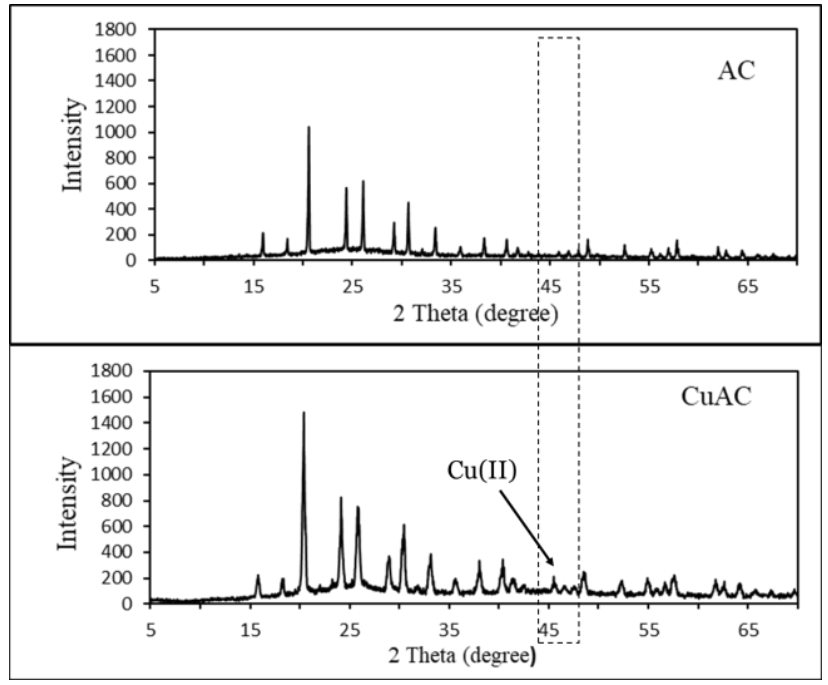

Figure 6. XRD spectra of AC and CuAC

\section{Removal of Dyes using CuAC}

The $10.00 \mathrm{ppm}$ of CR was used as dye sample. The control experiment has been done in 90 min without the presence of $\mathrm{CuAC}$ at $\mathrm{pH}$ 2. It was observed that the $\mathrm{CR}$ colour changed from orange to violet at $\mathrm{pH} 2$ and no significant changes were seen from $15 \mathrm{~min}$ to $90 \mathrm{~min}$ at room temperature (Figure 7. (A)). The changes of dye concentration have been proven using UV-VIS spectroscopy. The result obtained showed that the concentration of dye slightly decreased from $10.00 \mathrm{ppm}$ to $9.42 \mathrm{ppm}$ at $90 \mathrm{~min}$.

The experiment was repeated with the presence of $0.1 \mathrm{~g}$ of CuAC. The dye colour intensity clearly decreased in the Figure 7. (B) with the concentration decreasing from 10.00 ppm to $0.58 \mathrm{ppm}$. Consequently, it is shown that the $\mathrm{CuAC}$ had dye removal capability. Further study has been done to confirm the performance of $\mathrm{CuAC}$ as dye removal in the following discussion.

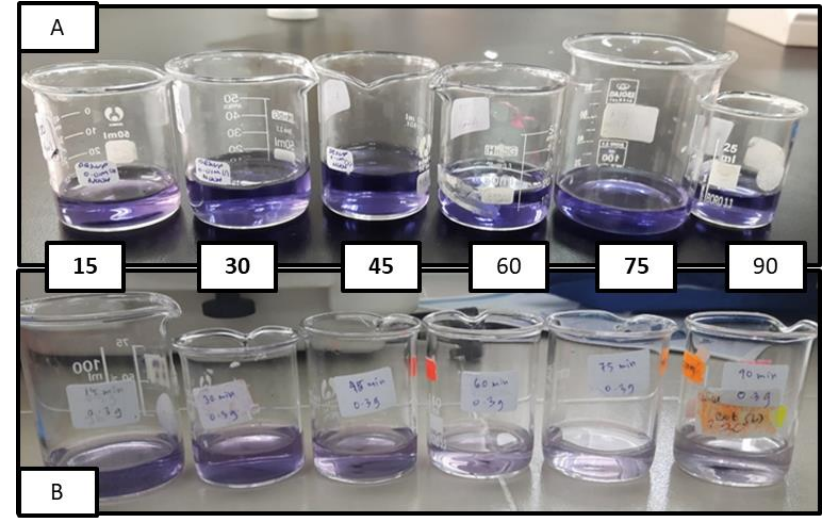

Figure 7. Changes of CR colour intensity in control experiment

\section{Optimization study}

The experiments were conducted with various parameters such as effect of $\mathrm{pH}$, the presence of light and different mass of $\mathrm{CuAC}$. All experiments were conducted using $10.00 \mathrm{ppm}$ of dyes and 90 min reaction time. The sample was taken at each 15 min interval.

\section{Effect of $p H$}

The \% removal of $\mathrm{CR}$ dyes at different $\mathrm{pH}$ conditions is illustrated in Figure 8. Within 90 min the \% removal of dye using $0.1 \mathrm{~g} \mathrm{CuAC}$ were $94.25 \%, 67.1 \%$ and $62.78 \%$ at $\mathrm{pH} 2, \mathrm{pH}$ 7 and pH 10, respectively. The \% removal of dye was higher in acidic condition $(\mathrm{pH} 2)$ because the abundant positive charges at the surface of $\mathrm{CuAC}$ were attracted to the negative charges of $\mathrm{CR}$ dye structure. The positive ions from $\mathrm{Cu}^{2+}$ were on the surface of $\mathrm{CuAC}$ itself and additional $\mathrm{H}^{+}$ions were from $\mathrm{HCl}$ during the $\mathrm{pH}$ controlling process (Shu et al., 2017; Sahoo et al., 2019).

In neutral and basic conditions, the \% removal of dye was lower. $\mathrm{OH}^{-}$ion formed during the addition of $\mathrm{NaOH}$ led to deactivation of $\mathrm{CuAC}$ surface (Shu et al., 2017). Increasing the basicity of reaction condition decreased the \% removal of dye due to increasing electrostatic repulsion that occurred between the negative charge of $\mathrm{CuAC}$ surface with the negative charge in the CR dye structure (Sahoo et al., 2019). 


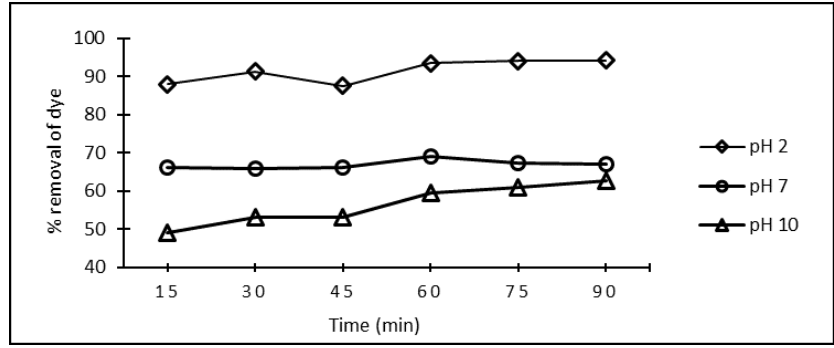

Figure 8. Effect of $\mathrm{pH}$ on \% removal of dye study

\section{Effect of light}

The dye removal experiment was conducted with and without the presence of light using $0.1 \mathrm{~g}$ of $\mathrm{CuAC}$ at $\mathrm{pH}$ 2. The results are revealed in Figure 9. The \% removal of dye showed no significant difference between with or without the presence of light. The result shows that light did not give a great impact in the removal of dyes. This result proved that the removal of dyes can be done independently with CuAC. In this study, the $\mathrm{CuAC}$ had two functions in dye removal which are as a catalyst with the presence of $\mathrm{Cu}^{2+}$ ion on its surface that helped the dye degradation and as an adsorbent with a great number of active sites on CuAC that cause outstanding colourant adsorption (Shu et al., 2017; Rabbani et al., 2019).

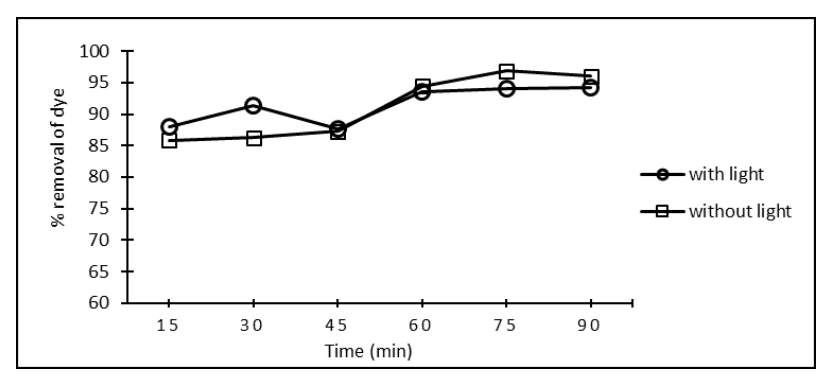

Figure 9. Effect of light on \% removal of dye study

\section{Effect of CuAC mass}

The removal of dyes influenced by different mass of $\mathrm{CuAC}$ was studied at $\mathrm{pH}$ 2. The results obtained are shown in Figure 10. The \% removal of dye at 90 min were $94.25 \%$ using $0.1 \mathrm{~g}$ of
$\mathrm{CuAC}$, and $100 \%$ using $0.2 \mathrm{~g}$ and $0.3 \mathrm{~g}$ of CuAC. Within the time of reaction from $15 \mathrm{~min}$ to $90 \mathrm{~min}$, there was no significant difference in \% removal of dye using $0.2 \mathrm{~g}$ or $0.3 \mathrm{~g}$ of $\mathrm{CuAC}$. Thus, the most suitable mass of $\mathrm{CuAC}$ for removal of dye at $10.00 \mathrm{ppm}$ was $0.2 \mathrm{~g}$ which is cost-saving. The $\mathrm{CuAC}$ can act as dye removal at small amounts due to higher surface area and abundance of pores on its surface, leading to higher efficiency as dye removal. In addition, the capacity of CR adsorption increases with higher amount of $\mathrm{CuAC}$ used due to more adsorption sites was available for the process of adsorption (Chanzu et al., 2019).

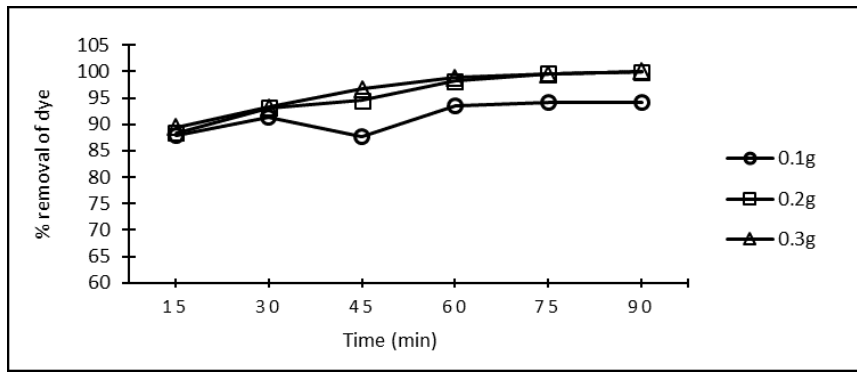

Figure 10. Effect of CuAC mass on removal of dye study

\section{CONCLUSION}

The CuAC from date seed has been successfully synthesised and used as CR dye removal. The optimum condition to remove $100 \%$ of $10.00 \mathrm{ppm}$ CR dye in aqueous solution was confirmed. The best condition was at $\mathrm{pH} 2$, with mass of $\mathrm{CuAC}$ at $0.2 \mathrm{~g}$ and $90 \mathrm{~min}$ reaction time.

\section{ACKNOWLEDGEMENT}

The author would like to thank the Faculty of Applied Sciences, Universiti Teknologi MARA, Cawangan Negeri Sembilan, Kampus Kuala Pilah for the research facilities provided and FRGS/1/2017/WABo5/UITM/03/2 research grant for financial support.

10.17758/EIRAI.Ho217302.

Aldawsari, A, Khan, MA, Hameed, BH, Alqadami, AA, Siddiqui, MR, Alothman, ZA, \& Ahmed, AYBH 2017, 'Mercerized mesoporous date pit activated carbon-A novel 
adsorbent to sequester potentially toxic divalent heavy metals from water', PloS one, vol. 12, no. 9, e0184493. doi: 10.1371/journal.pone.0184493.

Berkane, N, Meziane, S \& Aziri, S 2020, 'Optimization of Congo Red removal from aqueous solution using Taguchi experimental design', Journal of Separation Science and Technology, vol. 55, no. 2, pp. 278-288. doi: 10.1080/01496395.2019.1577442.

Chanzu, HA, Onyari, JM \& Shiundu, PM 2019, 'Brewers' spent grain in adsorption of aqueous Congo Red and malachite Green dyes: batch and continuous flow systems', Journal of Hazardous Materials, vol. 380, pp. 1-8 doi: 10.1016/j.jhazmat.2019.120897.

Chavan, RB 2011, Environmentally friendly dyes, Handbook of Textile and Industrial Dyeing: Principles, Processes and Types of Dyes vol. 1, Clark, M eds, Woodhead Pbl., Cambridge, United Kingdom, pp. 515-561.

Chen, H, Wageh, S, Al-Ghamdi, AA, Wang, H, Yu, J \& Jiang, C 2019, 'Hierarchical $\mathrm{C} / \mathrm{NiO}-\mathrm{ZnO}$ nanocomposite fibers with enhanced adsorption capacity for Congo Red', Journal of Colloid and Interface Science, vol. 537, pp. 736-745. doi: 10.1016/j.jcis.2018.11.045.

Dias, JM, Maria, CM, Alvim-Ferraz, Almeida, MF, RiveraUtrilla, J \& Sanchez Polo, M 2007, 'Waste materials for activated carbon preparation and its use in aqueous-phase treatment: a review', Environmental Management, vol. 85, no. 5, pp. 833-846. doi: 10.1016/j.jenvman.2007.07.031.

Foo, KY \& Hameed, BH 2010, 'Insights into the modeling of adsorption isotherm systems', Chemical Engineering Journal, vol. 156, no. 1, pp. 2-10. doi: 10.1016/j.cej.2009.09.013.

Hilal, NM, Ahmed, IA \& El-Sayed, RE 2012, 'Activated and nonactivated date pits adsorbents for the removal of copper(ii) and cadmium(ii) from aqueous solutions', ISRN Physical Chemistry, pp. 1-11. doi: 10.5402/2012/985853.

Huang, CC, Chen, CH \& Chu, SM 2006, 'Effect of moisture on $\mathrm{h}_{2} \mathrm{~S}$ adsorption by copper impregnated activated carbon', Journal of Hazardous Materials, vol. 136, no. 3, pp. 866873. doi: 10.1016/j.jhazmat.2006.01.025.

Hussein, FH, Halbus, AF, Lafta, AJ \& Athab, ZH 2015, 'Preparation and characterization of activated carbon from Iraqi Khestawy date palm', Journal of Chemistry, pp. 1-8. doi: 10.1155/2015/295748.

Iqbal, J, Shah, NS, Sayed, M, Imran, M, Muhammad, N, Howari, FM, Alkhoori, SA, Khan, JA, Khan, ZUH, Bhatnagar, A, Polychronopoulou, K, Ismail, I \& Haija, MA 2019, 'Synergistic effects of activated carbon and nano- zerovalent copper on the performance of hydroxyapatitealginate beads for the removal of $\mathrm{As}^{3+}$ from aqueous solution', Journal of Cleaner Production, vol. 235, pp. 875886. doi: 10.1016/j.jclepro.2019.06.316.

Jamion, NA, Abd Hafiff, NH, Abd Halim, NH \& Sheikh Mohd Ghazali, SAI 2017, 'Preparation of date seed activation for surfactant recovery', Malaysian Journal of Analytical Sciences, vol. 21, no. 5, pp. 1045-1053. doi: 10.17576/mjas2017-2105-06.

Kaur, S, Rani, S \& Mahajan, RK 2012, 'Congo Red biowaste material', Journal of Chemistry, pp. 1-12. doi: $10.1155 / 2013 / 628582$.

Khodaie, M, Ghasemi, N, Moradi, B \& Rahimi, M 2013, 'Removal of methylene blue from wastewater by adsorption onto $\mathrm{ZnCl}$ activated corn husk carbon equilibrium studies', Journal of Chemistry, pp. 1-6. doi: 10.1155/2013/383985. Krishnamoorthy, R, Govindan, B, Banat, F, Sagadevan, V, Purushothaman, M \& Show, PL 2019, 'Date pits activated carbon for divalent lead ions removal', Journal of Bioscience and Bioengineering, vol. 128, no. 1, pp. 88-97. doi: 10.1016/j.jbiosc.2018.12.011.

Manuel, S, Simone, B, Harpreet, KL, Rita, B \& Elena, B 2018, 'Energy dispersive X-ray (EDX) microanalysis: a powerful tool in biomedical research and diagnosis', European Journal of Histochemistry, vol. 62, no. 1, pp. 1-10. doi: 10.4081/ejh.2018.2841.

Nasron, AN, Azman, NS, Mohd Rashid, NSS \& Said, NR 2018, 'Degradation of Congo Red Dye in aqueous solution by using advanced oxidation processes', Journal of Academia, vol. 6, no. 2, pp. 1-11.

Oboh IO, Inyang UE, Aduak OJ, Ohon EE 2018, 'Removal of congo red and methylene blue dyes in aqueoues solution using copper (II) oxide nanoparticles', NSChE Journal, vol. 33 , no. 1 , pp. 95 .

Ogungbenro, AE, Quang, DV, Al-Ali, K \& Abu-Zahra, MRM 2017, 'Activated carbon from date seeds for $\mathrm{CO}_{2}$ capture applications', Energy Procedia, vol. 114, pp. 2313-2321. doi: 10.1016/j.egypro.2017.03.1370.

Rabbani, F, Shaikh, AJ, Khan, J, Ajaz, H, Rafique, M, Khan, ZUH., Ali, Z, Hussain, H, Gillani, MM, Aslam., K \& Shah, GM 2019, 'Removal of organic colorants using nano copper antimony oxychloride synthesized by non-solvated system', Journal of Inorganic and Organometallic Polymers and Materials, vol. 29, no. 3, pp. 893-900. doi: 10.1007/s10904018-01063-2.

Reddy, KSK., Al Shoaibi, A \& Srinivasakannan, C 2015, 'Impact of process conditions on preparation of porous 
carbon from date palm seeds by $\mathrm{KOH}$ activation', Clean Technologies and Environmental Policy, vol. 17, no. 6, pp. 1671-1679. doi: 10.1007/s13762-013-0468-9.

Sahoo, JK, Paikra, SK, Mishra, M \& Sahoo, H 2019, 'Amine functionalized magnetic iron oxide nanoparticles: synthesis, antibacterial activity and rapid removal of Congo red dye', Journal of Molecular Liquids, vol. 282, pp. 428-440. doi: 10.1016/j.molliq.2019.03.033.

Salman, JM, Hassan, FM \& Jouda, SA 2015, 'Removal of Congo Red dye from aqueous solution by using natural materials preparation of adsorbent effect of adsorbent dose', Mesopotamia Environmental, vol. 1, no. 3, pp. 82-89.

Shah, NS, Khan, JA, Sayed, M, Khan, ZUH, Iqbal, J, Arshad, $\mathrm{S}$, Junaid, M \& Khan, HM 202O, 'Synergistic effects of $\mathrm{H}_{2} \mathrm{O}_{2}$ and $\mathrm{S}_{2} \mathrm{O}_{8}{ }^{2-}$ in the gamma radiation induced degradation of congo red dye: kinetics and toxicities', Separation and Purification Technology, vol. 233, pp. 1-9. doi: 10.1016/j.seppur.2019.115966.

Shu, J, Cheng, S, Xia, H, Zhang, L, Peng, J, Li, C \& Zhang, S 2017, 'Copper loaded on activated carbon as an efficient adsorbent for removal of methylene blue', RSC Advances, vol. 7, no. 24, pp. 14395-14405. doi: 10.1039/c7raoo287d. Wang, X, Liang, X, Wang, Y, Wang, X, Liu, M, Yin, D \& Zhang, $Y$ 2011, 'Adsorption of copper(ii) onto activated carbons from sewage sludge by microwave-induced phosphoric acid and zinc chloride activation', Desalination, vol. 278, no. 13, pp. 231-237. doi: 10.1016/j.desal.2011.05.033. 